\title{
Edukasi Bahaya Sampah Plastik pada Perairan dan Biota Laut di Sekolah Alam, Pantai Bajulmati, Kabupaten Malang, Jawa Timur
}

\author{
1,2*Dian Aliviyanti, ${ }^{1,2}$ Rarasrum Dyah Kasitowati, ${ }^{1,3}$ Defri Yona, ${ }^{1,2}$ Bambang Semedi, ${ }^{1,4}$ Rudianto, \\ ${ }^{1,2}$ Muhammad Arif Asadi, ${ }^{1,2}$ Andik Isdianto, ${ }^{1,2}$ Citra Satrya Utama Dewi
}

\begin{abstract}
${ }^{1}$ Program Studi Ilmu Kelautan, Fakultas Perikanan dan Ilmu Kelautan, Universitas Brawijaya, Indonesia ${ }^{2}$ Coastal Resilience and Climate Change Adaptation (CORECT) Research Group, Universitas Brawijaya, Indonesia

${ }^{3}$ Marine Resources Exploration and Management (MEXMA) Research Group, Universitas Brawijaya, Indonesia

${ }^{4}$ Integrated Coastal Ecosystem Restoration and Sustainable Development (ICESSMENT) Research Group, Universitas Brawijaya, Indonesia

*Penulis korespondensi, email: alviyantidian@ub.ac.id
\end{abstract}

(Received: 19 November 2021/Accepted: 27 January 2022/Published: 31 January 2022)

\begin{abstract}
Abstrak
Plastik merupakan salah satu bahan pencemar yang banyak ditemukan di perairan laut. Dampak negatif langsung dari limbah plastik pada biota laut, dapat menyebabkan penyumbatan pada saluran pencernaan apabila termakan baik secara langsung ataupun tidak langsung. Salah satu upaya pengurangan limbah plastik adalah dengan membangun kesadaran dan kesiapan masyarakat untuk berpatisipasi secara aktif dalam menyelesaikan masalah sampah plastik. Oleh karena itu Program Studi Ilmu Kelautan, FPIK, Universitas Brawijaya melakukan kegiatan pengabdian kepada masyarakat dengan memberikan edukasi mengenai bahaya sampah plastik bagi perairan dan biota laut pada sekolah alam rintisan kelompok masyarakat Bajulmati Sea Turtle Conservation (BSTC) yang berada di Patai Bajulmati, Kabupaten Malang, Jawa Timur. Secara umum kegiatan pengabdian masyarakat berlangsung secara daring dan luring. Metode edukasi yang diberikan pada peserta didik adalah metode pembelajaran partisipatif dan kolaboratif, yaitu dengan memberikan pemahaman materi melalui bercerita di kelas dan kegiatan praktik pemilahan sampah plastik di lapangan. Hasil kegiatan edukasi bahaya sampah plastik dapat meningkatkan pengetahuan dan kesadaran masyarakat terutama peserta didik di sekolah alam BSTC sehingga nantinya akan berpengaruh terhadap perilaku penggunaan plastik yang lebih bijak. Melalui kegiatan tersebut diharapkan dapat menumbuhkan rasa cinta terhadap lingkungan dan juga dapat berpengaruh terhadap penggunaan plastik yang lebih baik.
\end{abstract}

Kata Kunci: Limbah plastik, ekosistem laut, BSTC, Kabupaten Malang

\begin{abstract}
Plastic is one of the most common pollutants found in marine waters. The direct negative impact of plastic waste on marine organisms is causing blockages in the digestive tract if eaten either intentionally or unintentionally. One of the efforts to reduce plastic waste is to build public awareness and readiness to actively participate in solving the problem of plastic waste. Therefore, Marine Science Study Program, FFMS, Universitas Brawijaya is dedicated to provide education about the dangers of plastic waste for aquatic communities and marine biota at a pioneering nature school for the Bajulmati Sea Turtle Conservation (BSTC) community in Bajulmati Beach, Malang Regency, East Java. In general, community service activities take place in online and offline manner. The educational methods given to students are a participatory and collaborative learning method, namely by providing an understanding of the material through class discussions and practical waste sorting activities in the field. The results of educational activities on the dangers of plastic waste can increase public knowledge and awareness, especially students at the BSTC nature school so that later it will have an effect on wiser plastic
\end{abstract}


use behavior. Through this activity, it is expected that the resulted knowledge and awareness can foster a sense of love for the environment and can also affect a better use of plastic.

Keywords : Plastic waste, marine ecosystem, BSTC, Malang Regency

\section{Pendahuluan}

Dinamika perairan laut yang fluktuatif, baik dari segi fenomena alam maupun yang diakibatkan oleh aktivitas manusia (antropogenik) dapat menimbulkan resiko pada kelestarian ekosistem laut. Salah satu aktivitas manusia yang banyak mempengaruhi laut dan kehidupan biota didalamnya adalah masukan sampah atau limbah secara langsung ke laut, seperti plastik (Cordova, 2017). Berdasarkan data BPS (2021) program pengelolaan sampah Kabupaten Malang pada Tahun 2020 sebesar $5.080 \mathrm{~m}^{3} /$ hari mengalami penurunan bila dibandingkan dengan Tahun 2017 yang mencapai $5.813 \mathrm{~m}^{3} /$ hari. Meskipun terjadi penurunan angka pengelolaan sampah, namun nilai timbulan sampah harian yang mencapai $5.080 \mathrm{~m}^{3}$ masih dikategorikan tinggi. Belum lagi kebiasaan masyarakat umum membuang sampah tidak pada tempatnya yang berujung ke laut, tentunya menjadi ancaman kelestarian lingkungan. Oleh sebab itu perlu dilakukan upaya pencegahan dan perlindungan ekosistem laut secara masal ataupun secara khusus.

Salah satu upaya pengurangan penggunaan sampah plastik dapat dilakukan dengan memberikan edukasi mengenai bahaya sampah plastik sedini mungkin pada anak usia sekolah. Kelompok masyarakat Bajulmati Sea Turtle Conservation (BSTC) yang berlokasi di Pantai Bajulmati, Kabupaten Malang, Jawa Timur telah merintis sekolah alam yang ditujukan bagi anakanak usia sekolah di sekitar wilayah pantai Bajulmati (Gambar 1). Sekolah ini memberikan pembelajaran mengenai dunia perikanan dan kelautan. Salah satu tujuannya adalah untuk mengenalkan sumberdaya perikanan dan kelautan sertacara pemanfaatannya. Sekolah ini merupakan hasil dari swadaya masyarakat, bersifat informal dan bebas biaya. Seiring dengan berjalannya waktu, terdapat beberapa persoalan yang dihadapi oleh mitra.

Permasalahan pertama yaitu minimnya sumberdaya pengajar yang memiliki bidang keahlian tentang kelautan. Pembelajaran yang selama ini diberikan pada peserta didik sekolah alam adalah mengenai budidaya ikan dan penangkapan ikan. Belum adanya pembelajaran yang mengarah pada kelestarian lingkungan, terutama edukasi tentang pencemaran laut akibat limbah plastik, karena minimnya sumberdaya yang dimiliki oleh pengelola sekolah.

Permasalahan lain yaitu kurangnya sarana prasarana penunjang kegiatan pembelajaran. Sarana dan prasaranapendukung merupakan faktor penting dalam keberhasilan pembelajaran. Dengan keterbatasan dana dalam pengelolaan sekolah alam ini menyebabkan minimnya saranaprasarana yang dimiliki dan dapat mempengaruhi keberhasilan pembelajaran. Sekolah alam ini masih banyak memerlukan sarana prasarana seperti alat peraga pendidikan, alat sampling, dan lemari penyimpanan sarana pendidikan.

Pada umumnya edukasi yang diberikan di sekolah dasar dilakukan secara tutorial yaitu guru menjelaskan dan peserta didik mendengarkan. Perlu adanya metode pembelajaran baru yang lebih menarik dan demonstratif bagi anak-anak usia sekolah dasar sehingga dapat menarik minat anak-anak terhadap topik pembelajaran yang diberikan. Salah satu metode pembelajaran yang kami berikan yaitu metode partisipasi aktif. Metode pembelajaran partisipatif dan kolaboratif dapat dilakukan dengan mengajak peserta didik ke wilayah pantai untuk mengenali langsung jenis-jenis sampah plastik sehingga mampu membedakan jenis-jenis sampah plastik ataupun non-plastik.

Berdasarkan permasalahan-permasalahan yang dihadapi oleh mitra, maka PS Ilmu Kelautan FPIK UB melakukan kegiatan pengabdian masyarakat pada lokasi tersebut. Kegiatan ini bertujuan untuk memberikan edukasi pada anak-anak usia dini (SD-SMP) tentang bahaya sampah plastik bagi lingkungan perairan dan biota laut. Melalui kegiatan pengabdian ini 
diharapkan dapat menumbuhkan kesadaran lingkungan sejak dini dan menciptakan peluang lahirnya generasi yang tanggap terhadap lingkungan.

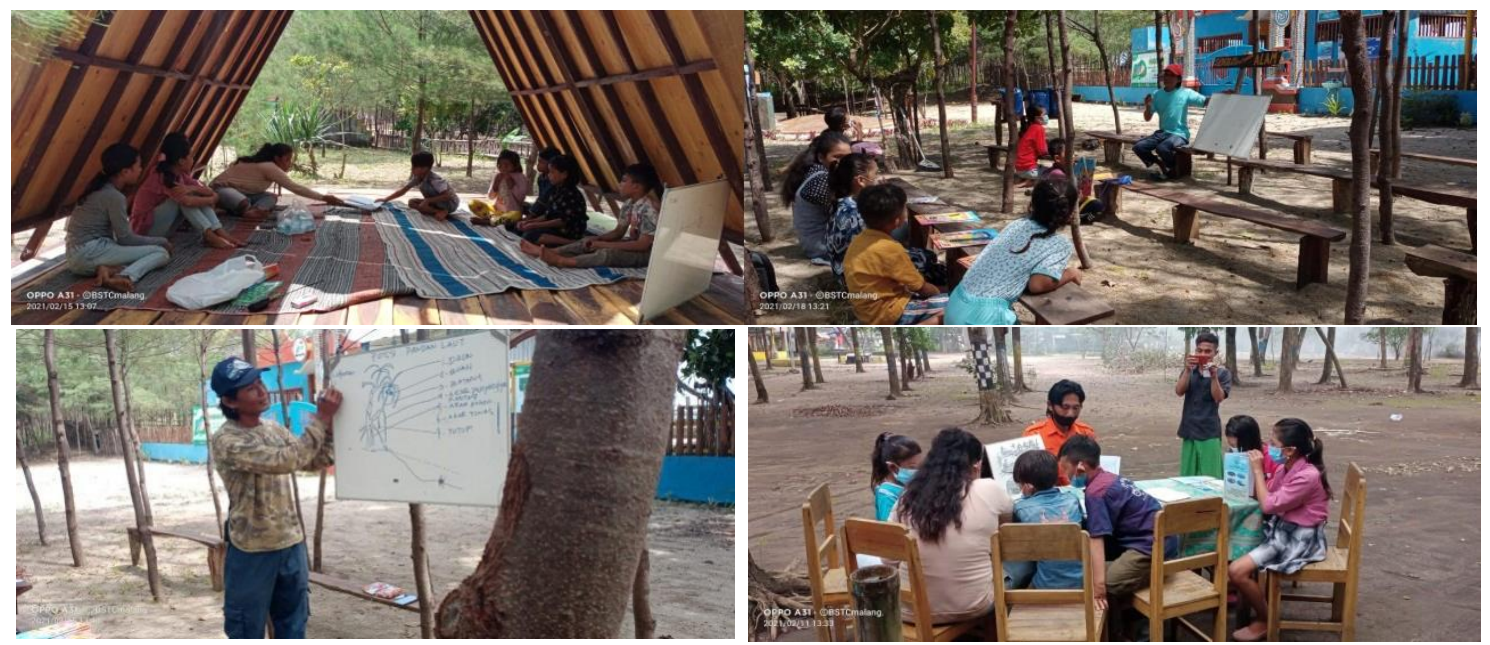

Gambar 1. Kegiatan belajar-mengajar yang sudah dilakukan di Sekolah Alam BSTC (Sumber: BSTC).

\section{Metode}

Pengabdian kepada masyarakat ini dilakukan dengan serangkaian tahapan kegiatan secara daring dan luring. Puncak kegiatan dilakukan secara luring pada tanggal 11 September 2021 di Pantai Bajulmati, Kabupaten Malang, Jawa Timur (Gambar 2). Wilayah ini merupakan kawasan konservasi penyu yang dikelola oleh POKMASWAS Pilar Harapan dengan kegiatan utama yang bertajuk Bajulmati Sea Turtle Conservation (BSTC).

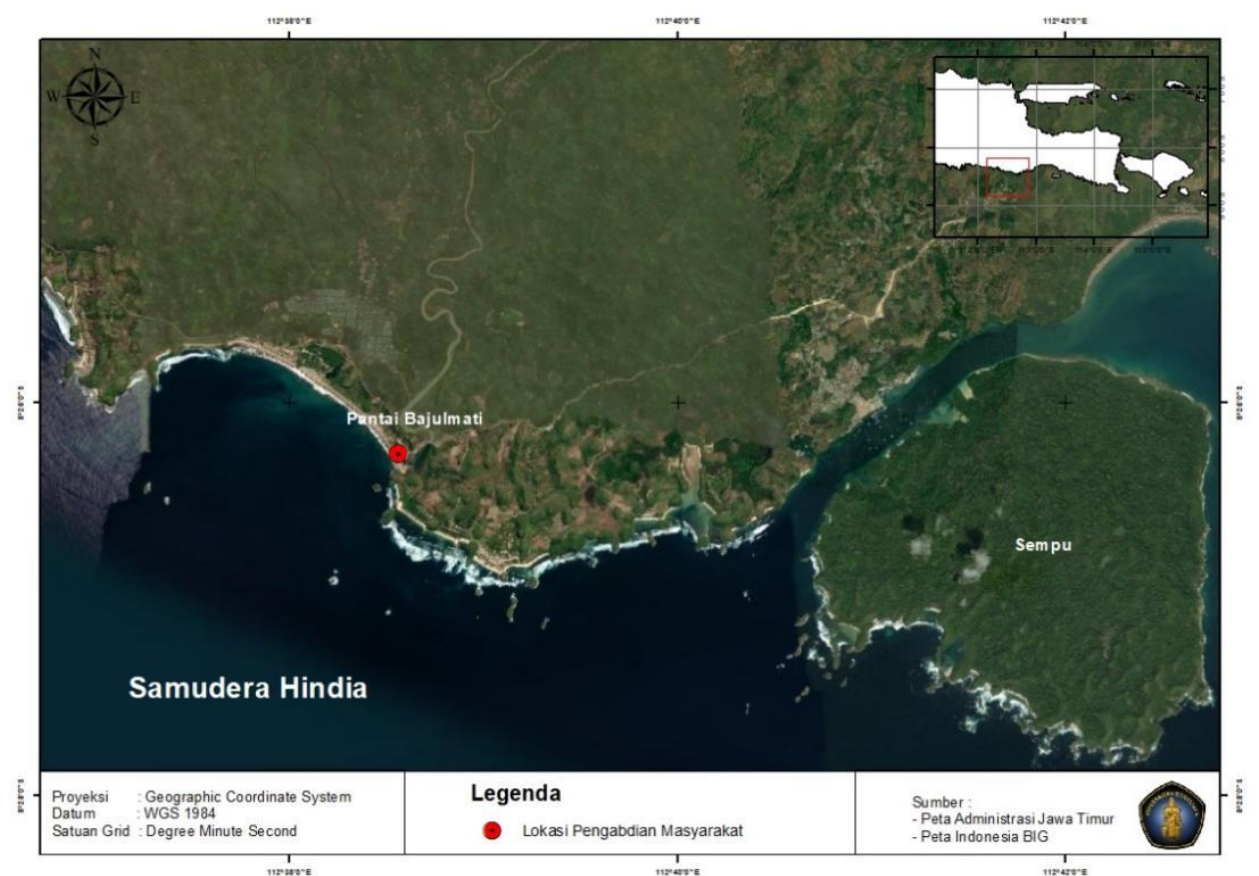

Gambar 2. Peta lokasi pengabdian masyarakat di Pantai Bajulmati Kabupaten Malang 
Adapun tahap pelaksanaan kegiatan pengabdian masyarakat ini dilakukan beberapa tahap yaitu tahap persiapan, pengabdian secara daring, dan tahap terakhir pengabdian secara luring (Gambar 3).

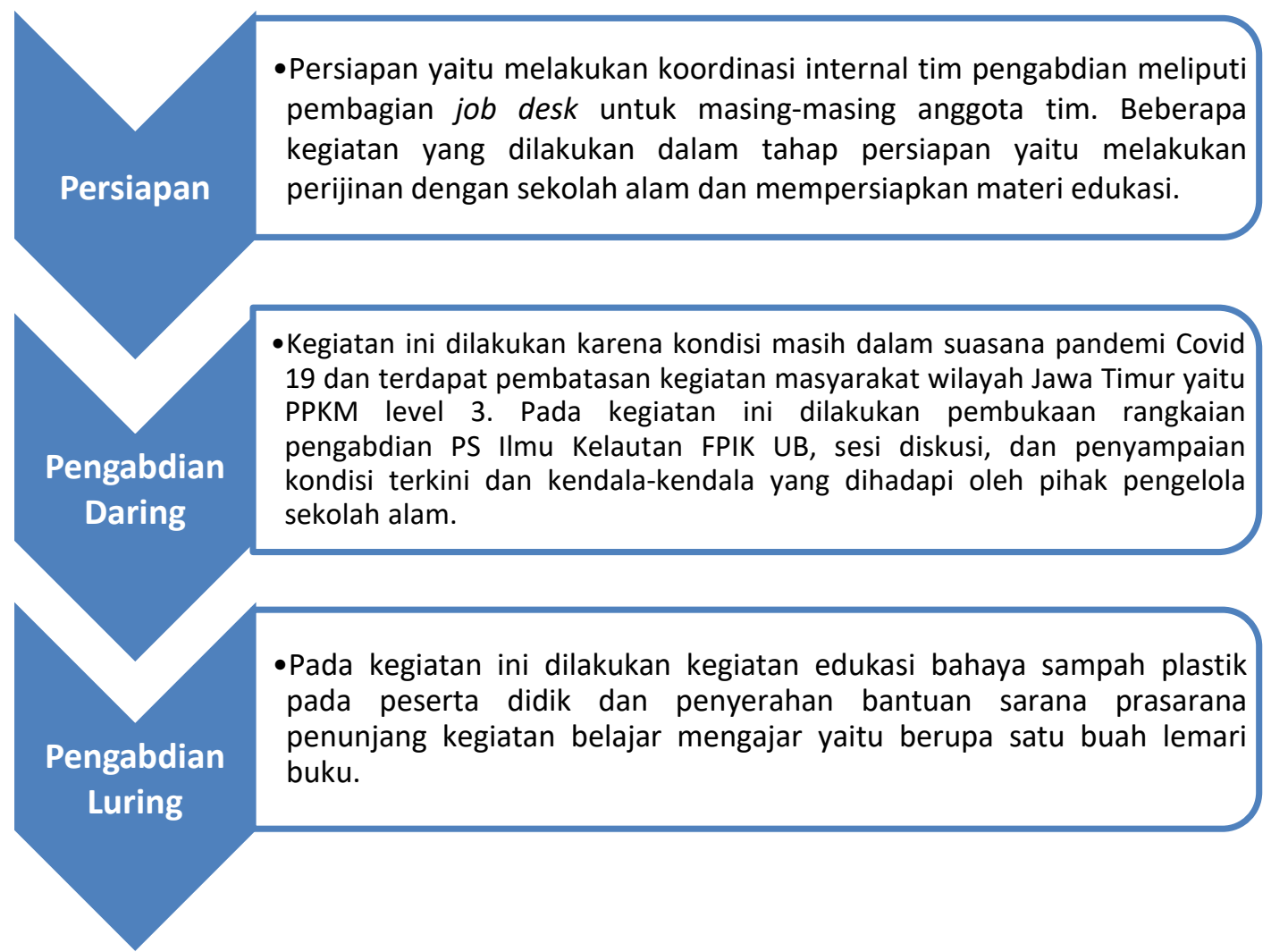

Gambar 3. Tahap pelaksanaan kegiatan pengabdian masyarakat.

Pada tahap pelaksanaan pengabdian secara luring, kegiatan edukasi dibagi menjadi dua tahap yaitu kegiatan edukasi dalam kelas dan kegiatan praktik di lapangan. Pada tahap pertama edukasi mengenai sampah plastik dan bahayanya pada perairan dan biota laut dilakukan dalam ruang kelas Sekolah Alam BSTC. Kegiatan ini dilakukan dengan metode bercerita (menjelaskan gambar-gambar pembelajaran kepada peserta didik) dan metode video based learning (penyampaian pengetahuan melalui pemutaran video menarik). Pada tahap kedua dilakukan praktik langsung peserta didik diajak untuk susur pantai dan mengenal langsung macam-macam sampah plastik, serta dibiasakan untuk melakukan respon langsung terhadap sampah plastik yang ditemui yaitu dengan memungut dan membuangnya pada tempat sampah.

\section{Hasil dan Pembahasan}

Rangkaian kegiatan pengabdian masyarakat Prodi Ilmu Kelautan FPIK UB dibagi menjadi dua tahap yaitu kegiatan pengabdian secara daring dan luring.

\section{1. Pengabdian Masyarakat Daring}

Kegiatan pengabdian masyarakat di Sekolah Alam BSTC tahun ini masih dalam kondisi pandemi Covid-19. Tahap persiapan dilaksanakan melalui rapat koordinasi secara daring dengan seluruh elemen dosen dan mahasiswa yang terlibat pada kegiatan ini. Selanjutnya pada tahap ini dilakukan pembagian tugas teknis yang meliputi pra kegiatan dan pelaksanaan, penyusunan jadwal dan rundown kegiatan, serta berkomunikasi dengan mitra POKMASWAS Pilar Harapan. 
Selain itu, dilakukan koordinasi kegiatan lapang ke sekolah alam sebelum pelaksanaan kegiatan pengabdian masyarakat secara luring.

Selanjutnya pada tahap ini, ditetapkan pula teknis kegiatan pengabdian masyarakat yaitu dilakukan secara daring dan juga luring. Kegiatan daring dilakukan pada tahap awal dan pembukaan rangkaian kegiatan pengabdian masyarakat (Gambar 4). Dan kegiatan luring dilakukan pada kegiatan inti yaitu edukasi bahaya sampah plastik pada perairan dan biota laut.

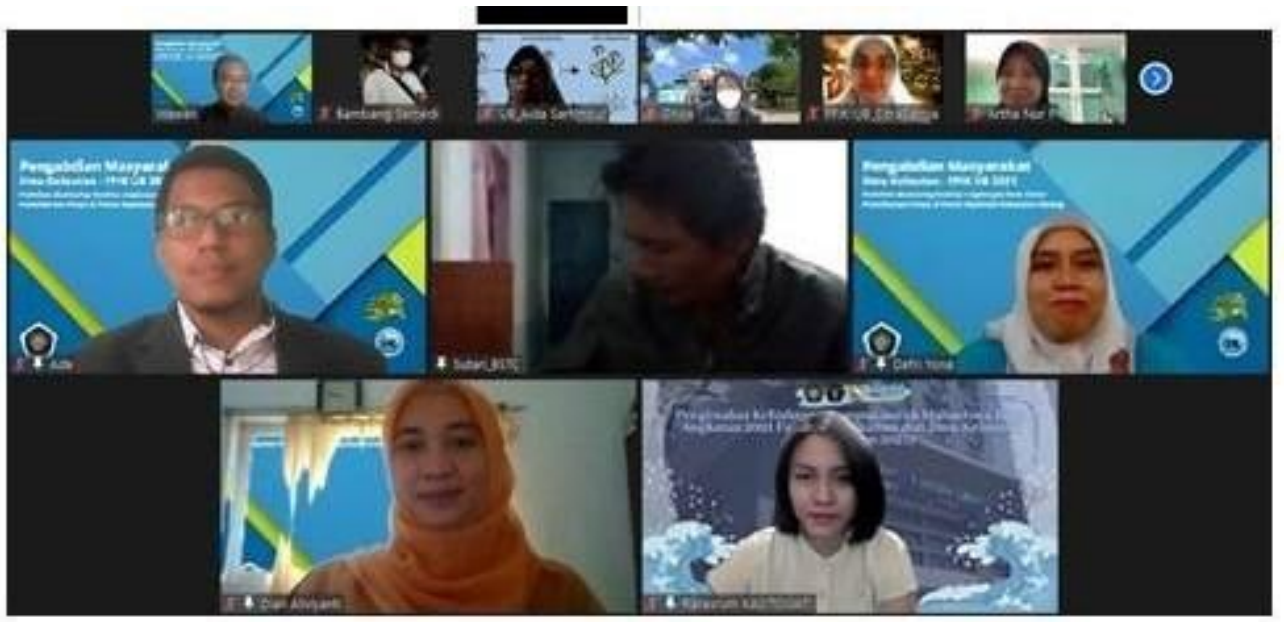

Gambar 4. Pembukaan kegiatan pengabdian masyarakat dilakukan secara daring.

Pada sesi pembukaan pengabdian masyarakat secara daring dilakukan pemaparan materi mengenai rangkaian agenda kegiatan yang akan dilakukan. Terdapat dua agenda kegiatan pengabdian masyarakat Prodi Ilmu Kelautan FPIK UB yang dilakukan bersama mitra Pokmaswas Pilar Harapan di Pantai Bajulmati. Selain kegiatan edukasi bahaya sampah plastik pada perairan dan biota laut, Prodi Ilmu Kelautan juga melakukan kegiatan pengabdian yang bertajuk pelatihan monitoring kualitas lingkungan pada kolam pemeliharaan penyu.

Sesi pemaparan materi yang pertama disampaikan oleh Bapak Ade Yamindago, S.Kel., MP., M.Sc., Ph.D. yang menjelaskan kegiatan pelatihan monitoring kualitas lingkungan pada kolam pemeliharaan penyu. Pada sesi ini dijelaskan prosedur monitoring dan simulasi beberapa alat yang akan diberikan pada Pokmaswas Pilar Harapan sebagai penunjang fasilitas pemeliharaan penyu. Selanjutnya sesi pemaparan materi yang kedua disampaikan oleh Ibu Rarasrum Dyah Kasitowati, S.Kel., M.Si., M.Sc. yang menjelaskan kegiatan edukasi bahaya sampah plastik pada perairan dan biota laut. Pada sesi ini dijelakan pula teknis pelaksanaan kegiatan edukasi yang akan dilakukan bersama peserta didik di Sekolah Alam BSTC.

Sesi berikutnya yaitu tanya jawab seputar rencana kegiatan yang akan dilakukan meliputi, kondisi terkini di lokasi dan permasalahan-permasalahan yang dihadapi oleh mitra. Salah satu permasalahan dalam proses belajar-mengajar yang dihadapi oleh Sekolah Alam BSTC saat ini adalah kondisi pandemi Covid-19 yang menyebabkan pembatasan kegiatan, jumlah siswa, dan aktivitas-aktivitas lain yang berpotensi menimbulkan kerumunan. Sehingga selama pandemi Covid-19 hampir seluruh kegiatan di Sekolah Alam BSTC dihentikan sementara. Bila memang harus dilakukan kegiatan luring, maka hanya dapat dihadiri oleh sedikit peserta dengan menerapkan protokol kesehatan yang lengkap. Sehingga berdasarkan informasi tersebut maka rencana kegiatan belajar mengajar secara luring dilakukan sesuai dengan prosedur yang diterapkan pada lokasi pengabdian masyarakat. 


\section{2. Pengabdian Masyarakat Luring}

Kegiatan pengabdian masyarakat secara luring dilakukan pada Hari Sabtu, Tanggal 11 September 2021. Kegiatan ini dihadiri oleh Ketua PS Ilmu Kelautan Defri Yona, S.Kel., M.Sc.Stud., D.Sc., bapak/ibu dosen, mahasiswa/alumni, perwakilan BKSDA Malang, dan tuan rumah Ketua dan Tim BSTC serta peserta didik sekolah alam. Tahap pelaksanaan kegiatan dibagi menjadi dua sesi, yaitu sesi edukasi dengan anak-anak sekolah alam BSTC dan sesi seremonial penyerahan bantuan alat berupa bantuan lemari buku. Berikut merupakan penjelasan selengkapnya.

\section{A. Edukasi}

Kegiatan edukasi bahaya sampah plastik dilakukan selama dua jam, dimulai pada pukul 09:00 - 11:00 WIB. Jumlah peserta yang mengikuti kegiatan ini dibatasi karena status Pemberlakuan Pembatasan Kegiatan Masyarakat (PPKM) level 3 pada lokasi pengabdian. Terdapat lima anak yang mengikuti proses edukasi bahaya sampah plastik pada perairan dan biota laut (Gambar 5). Proses kegiatan belajar-mengajar dimulai dari kegiatan kelas lalu dilanjutkan dengan kegiatan outdoor.
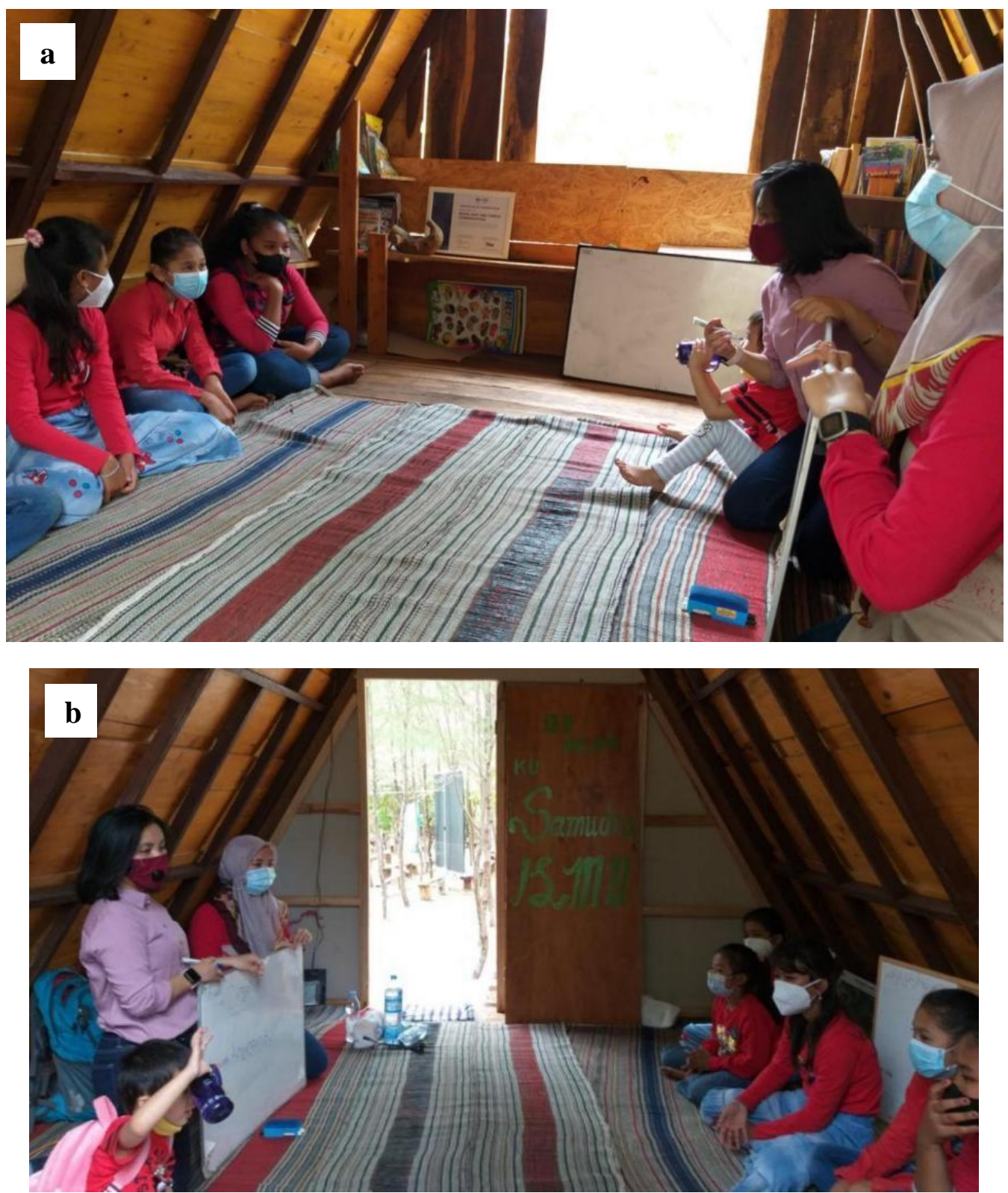

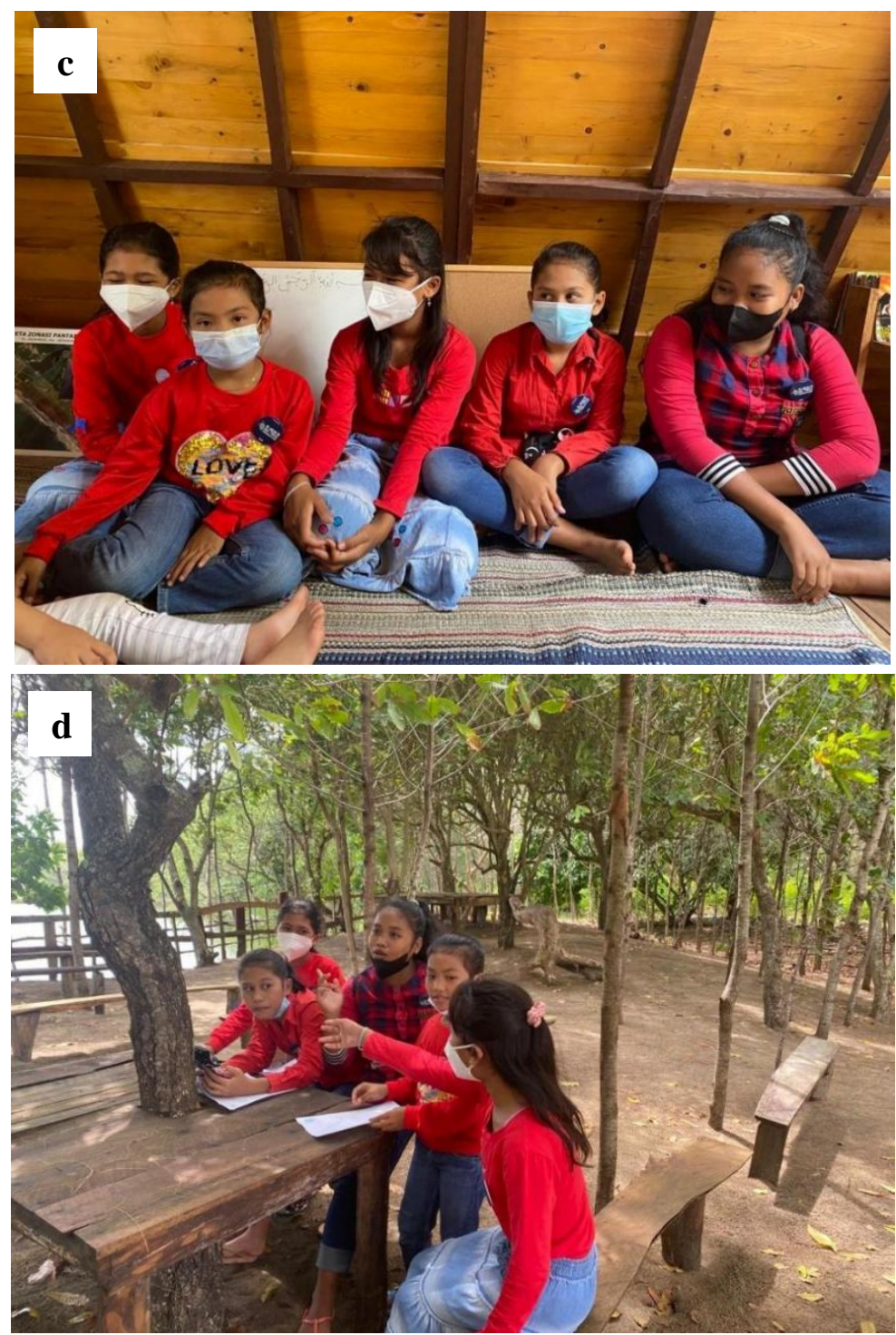

Gambar 5. Kegiatan edukasi sampah plastik di Sekolah Alam BSTC Kabupaten Malang: (a-c) kegiatan indoor; (d) kegiatan outdoor.

Pemateri yang hadir mengisi kegiatan edukasi bahaya sampah plastik pada biota dan ekosistem laut berjumlah dua orang yaitu dosen-dosen PS Ilmu Kelautan FPIK UB, Rarasrum Dyah Kasitowati, S.Kel, M.Si., M.Sc. dan Dian Aliviyanti, S.Si., M.Si. Kegiatan edukasi bahaya sampah plastik pada biota dan ekosistem laut dilakukan di ruang kelas sekolah alam BSTC yaitu dengan materi pengenalan jenis-jenis sampah plastik (Gambar 5a-c). Peserta didik yang hadir pada kegiatan tersebut terlihat antusias mengikuti proses pembelajaran. Hal tersebut ditandai dengan keaktifan peserta dalam berinteraksi dan menjawab pertanyaan-pertanyaan yang diberikan oleh pemateri.

Setelah dilakukan sesi edukasi dalam kelas dilanjutkan dengan kegiatan praktik pengenalan jenis-jenis sampah plastik di luar kelas (Gambar 5d). Melalui kegiatan praktik langsung diharapkan dapat menambah pemahaman peserta didik dalam membedakan jenis-jenis sampah, mulai dari jenis sampah organik, anorganik, hingga berbagai macam jenis sampah plastik yang dijumpai saat kegiatan praktik berlangsung. Berdasarkan data PlasticsEurope (2015), plastik bersifat ringan, kuat, tahan terhadap korosi, dan harganya yang murah menjadikan pemakaian plastik saat ini bersifat masif, hampir selalu ada disetiap produk kemasan kebutuhan sehari-hari. Limbah plastik merupakan jenis limbah yang bersifat persisten dan membutuhkan waktu yang 
lama untuk terurai di lingkungan secara alami (Law, 2017). Kemampuan daya apung plastik dapat mendistribusikan penyebaran plastik hingga jarak yang jauh, dan pada akhirnya mengendap pada sedimen selama berabad-abad (Li et al., 2016). Hal tersebut yang menyebabkan diperlukan penanganan khusus dalam menanggulangi limbah plastik agar tidak mencemari lingkungan perairan.

Semakin hari ancaman limbah plastik bagi lingkungan semakin nyata. Keeratan aktivitas sehari-hari masyarakat dengan berbagai bahan dari plastik menjadi salah satu faktor meningkatnya limbah plastik di lingkungan. Menurut Andrady (2011), lebih dari 75\% sampah plastik yang ada di laut adalah hasil dari masukan sampah plastik yang berada di darat. Hal yang lebih membahayakan lagi bagi lingkungan bukan hanya keberadaan limbah plastik dengan ukuran yang besar, namun jenis plastik yang sudah terdegradasi menjadi mikroplastik yang kini lambat laun menjadi ancaman yang nyata (Yona et al., 2019).

Mikroplastik merupakan fragmen atau potongan plastik yang berukuran sangat kecil yaitu \pm kurang dari $5 \mathrm{~mm}$ (Zhang et al., 2017). Hal tersebut menyebabkan mikroplastik dapat dengan mudah tertelan atau ditelan oleh biota yang ada di laut sehingga secara langsung akan mempengaruhi sistem pencernaannya. Dampak lain mikroplastik bagi biota adalah menyebabkan terjadinya perubahan struktur komunitas, translokasi sistem peradaran darah, kegagalan reproduksi, kecacatan pada masa perkembangan janin, penurunan kebugaran, hingga menimbulkan kematian (Laglbauer et al., 2014). Melalui kegiatan edukasi bahaya sampah plastik pada anak-anak di daerah pesisir diharapkan dapat menambah wawasan tentang bahaya sampah plastik baik bagi perairan dan biota, serta pentingnya menjaga kelestarian ekosistem laut. Selain itu diharapkan pula dapat menginisiasi munculnya kegiatan atau kelompok-kelompok masyarakat pengawas kelestarian laut dimasa yang akan datang.

\section{B. Penyerahan bantuan}

Penyerahan bantuan berupa lemari buku dilakukan secara simbolis dari Tim Pengabdian PS Ilmu Kelautan kepada Ketua Pokmaswas Pilar Harapan yang telah merintis sekolah alam BSTC (Gambar 6).

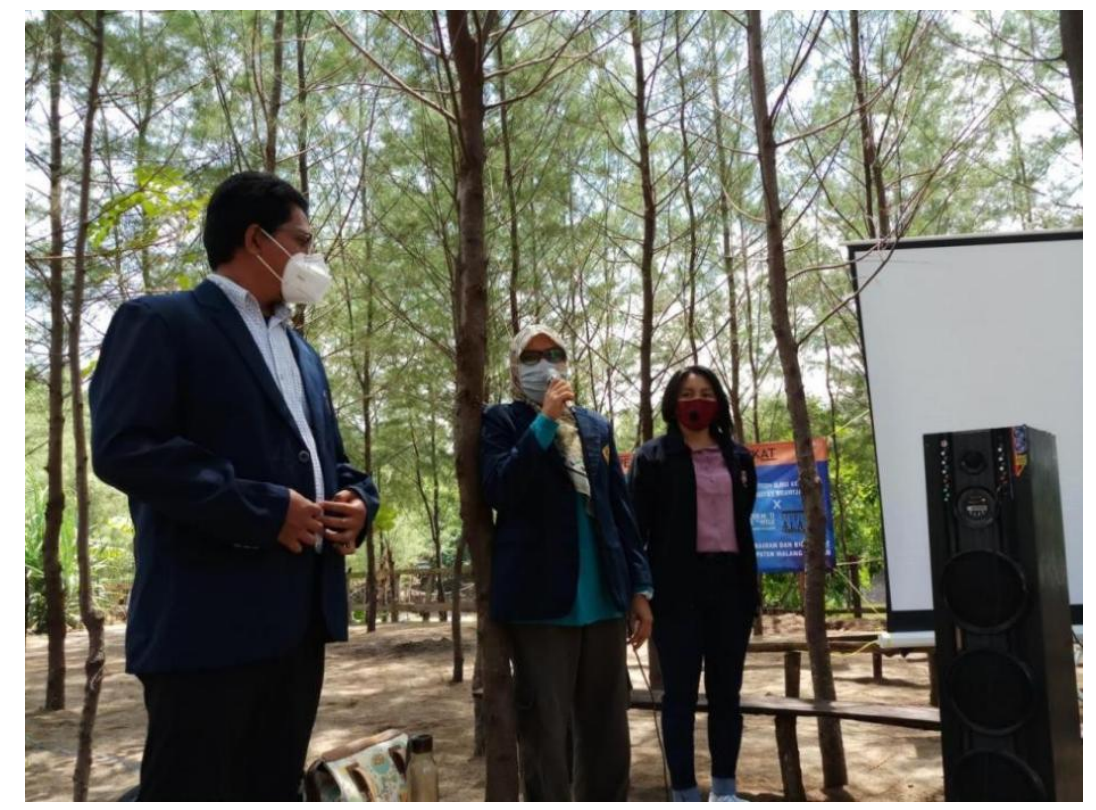



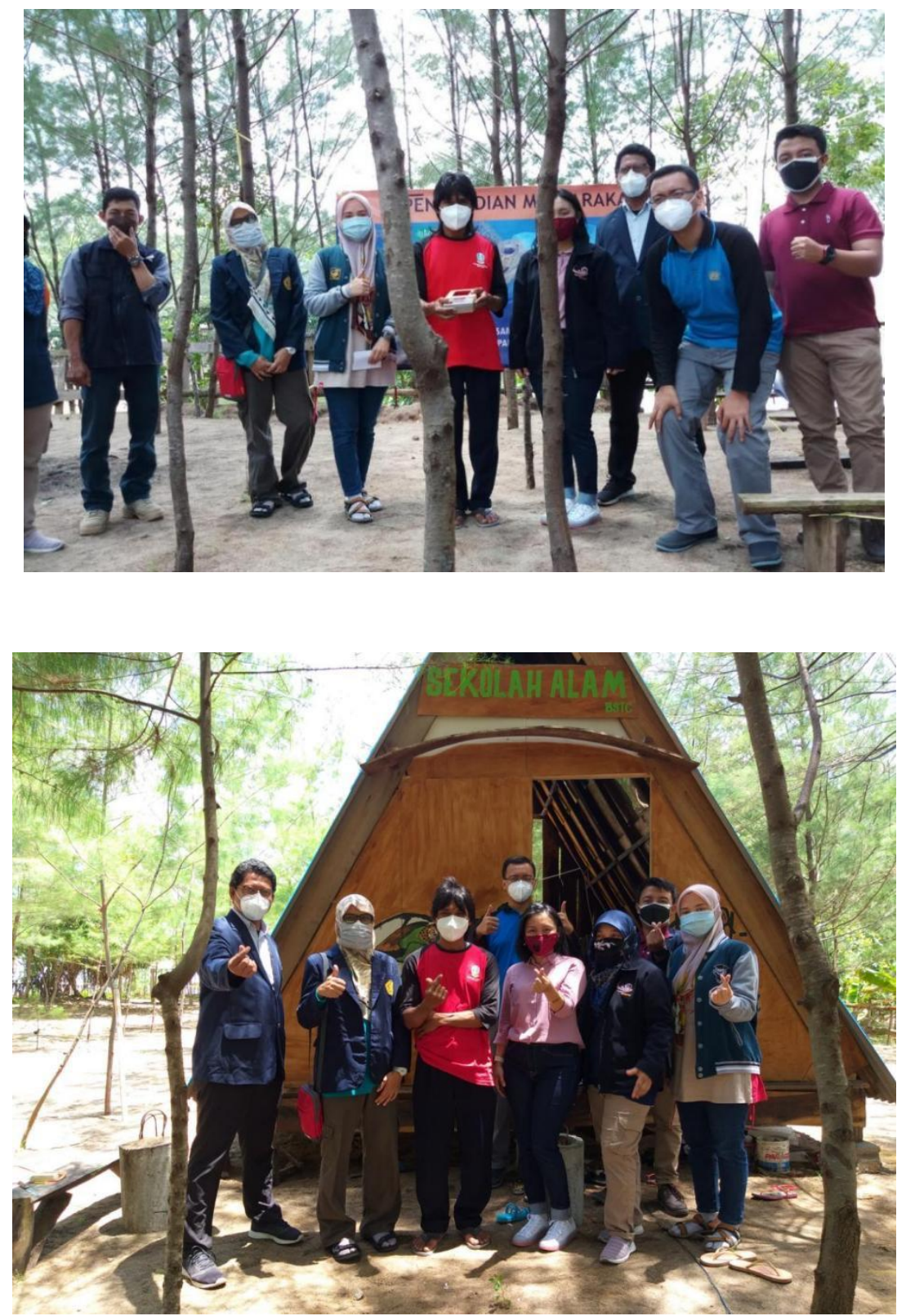

Gambar 6. Kegiatan simbolis serah terima bantuan lemari buku pada sekolah alam BSTC.

Pada kegiatan ini dilakukan serangkaian acara yaitu meliputi penyerahan bantuan peralatan monitoring kualitas lingkungan untuk kolam pemeliharaan penyu dan penyerahan bantuan sarana prasarana untuk sekolah alam BSTC. Salah satu upaya mendukung tersedianya sarana prasarana dalam kegiatan belajar mengajar di sekolah alam BSTC, tim pengabdian masyarakat PS Ilmu Kelautan FPIK UB memberikan sebuah lemari buku. Lemari buku dapat digunakan untuk menyimpan buku-buku dan inventaris lainnya dari sekolah alam BSTC. Lokasi Sekolah Alam BSTC yang terletak dekat dengan lautan berpotensi terkena berbagai macam perubahan kondisi cuaca ataupun fenomena oseanografi seperti salah satunya banjir ROB. Dengan adanya lemari buku diharapkan dapat membantu dalam penyimpanan buku dan dokumen-dokumen penting dari sekolah alam tersebut.

Pada kesempatan kali ini dilakukan juga diskusi mengenai keberlanjutan kegiatan pengabdian masyarakat di Sekolah Alam BSTC. Salah satu yang menjadi fokus bahasan adalah perlunya kaderisasi dari pemuda-pemudi di lingkungan tersebut untuk ikut andil dalam 
penyelenggaraan kegiatan belajar-mengajar di Sekolah Alam BSTC. Hal tersebut diperlukan karena dapat berperan sebagai mediator atau menjembatani komunikasi dengan pihak-pihak luar, baik dari pihak akademisi ataupun pihak-pihak lain yang berpotensi menjalin kerjasama dengan mitra. Karena pada akhirnya, pemenuhan sarana prasarana bila tidak didampingi dengan sumberdaya manusia yang baik maka tidak dapat berpengaruh secara maksimal terhadap keberlangsungan dan kesuksesan dari Sekolah Alam BSTC.

Secara umum kegiatan pengabdian masyarakat Prodi Ilmu Kelautan FPIK UB dinyatakan berhasil, metode edukasi partisipasi aktif efektif menumbuhkan semangat belajar peserta didik melalui kegiatan diskusi, tanya jawab, dan kegiatan praktik di lapangan. Penambahan sarana prasarana berupa lemari buku juga dapat menunjang kegiatan belajar mengajar di Sekolah Alam BSTC.

\section{Simpulan}

Kegiatan pengabdian masyarakat yang sudah dilakukan berlangsung dengan dua metode yaitu pengabdian secara daring dan luring. Kegiatan edukasi sampah plastik yang dilakukan pada jenjang anak sekolah dasar (SD-SMP) dapat memberikan pengalaman pembelajaran yang lebih melekat terhadap bahaya sampah plastik pada ekosistem laut. Serta melalui kegiatan ini dapat menumbuhkan kesadaran cinta lingkungan yang lebih tinggi, dan merubah kebiasaan konsumsi plastik secara berlebihan. Diharapkan melalui hasil dari kegiatan ini dapat menginisiasi munculnya aksi-aksi konservasi ekosistem laut dimasa yang akan datang. Bantuan penunjang sarana prasarana kegiatan belajar mengajar berupa lemari buku dapat bermanfaat dan digunakan untuk menyimpan buku serta inventaris lainnya dari sekolah alam BSTC.

Kegiatan edukasi bahaya sampah plastik pada biota dan lingkungan laut sangat dibutuhkan bagi masyarakat pesisir, terutama bagi anak-anak usia dini yang memiliki peran sebagai generasi penerus untuk menjaga kelestarian lingkungan di daerahnya. Perlu diadakan agenda kegiatan secara terjadwal dengan berbagai topik tema konservasi ekosistem laut untuk menambah pemahaman peserta didik. Serta untuk menunjang keberhasilan program ini perlu dilakukan kaderisasi dari kelompok remaja setempat agar dapat mempermudah komunikasi dengan pihak akademisi dalam melaksanakan kegiatan pembelajaran secara rutin.

\section{Persantunan}

Ucapan terima kasih ditujukan kepada Fakultas Perikanan dan Ilmu Kelautan Universitas Brawijaya atas dukungan dana pengabdian masyarakat melalui Hibah Penelitian dan Pengabdian Masyarakat Dosen FPIK (SK Dekan No. 91 Tahun 2021) Badan Penelitian dan Pengabdian Masyarakat (BPPM) FPIK UB serta seluruh pihak yang terlibat dalam kegiatan pengabdian ini.

\section{Referensi}

Andrady, A. L. (2011). Microplastics in the marine environment. Marine Pollution Bulletin, 62(8), 1596-1605. https://doi.org/10.1016/j.marpolbul.2011.05.030.

BPS. (2021). Kabupaten Malang dalam Angka: Malang Regency in Figures 2021. Kabupaten Malang: CV Kurnia.

Cordova, M.R. (2017). Pencemaran Plastik Di Laut. Oseana vol XLII No 3

Laglbauer, B. J. L., Franco-Santos, R. M., Andreu-Cazenave, M., Brunelli, L., Papadatou, M., Palatinus, A., Grego, M., \& Deprez, T. (2014). Macrodebris and microplastics from beaches in Slovenia. Marine Pollution Bulletin, 89(1-2), 356-366. https://doi.org/10.1016/j.marpolbul.2014.09.036

Law, K. L. (2017). Plastics in the Marine Environment. Annual Review of Marine Science, 9(1), 205-229. https://doi.org/10.1146/annurev-marine-010816-060409. 
Lestari, P.W., Septaria, B.C., Putri, C.E. (2020). EDUKASI "MINIM PLASTIK" SEBAGAI WUJUD CINTA LINGKUNGAN DI SDN PEJATEN TIMUR 20 PAGI. Jurnal Pengabdian Masyarakat, 16(1).

Li, W. C., Tse, H. F., \& Fok, L. (2016). Plastic waste in the marine environment: A review of sources, occurrence and effects. Science of The Total Environment, 566-567, 333-349. https://doi.org/10.1016/j.scitotenv.2016.05.084.

PlasticsEurope. (2015). Plastics - the Facts 2014/2015: An Analysis of European Plastics Production, Demand and Waste Data. Diakses dari http://issuu.com/ plasticseuropeebook/docs/fifinal_plastics_the_facts_2014_19122/1?e=5245759/137579 77.

Yona, D., Sari, S. H. J., Iranawati, F., Bachri, S., \& Ayuningtyas, W. C. (2019). Microplastics in the surface sediments from the eastern waters of Java Sea, Indonesia. F1000Research, 8: 98.

Zhang, C., Chen, X., Wang, J., \& Tan, L. (2017). Toxic effects of microplastic on marine microalgae Skeletonema costatum: Interactions between microplastic and algae. Environmental Pollution, 220, 1282-1288. https://doi.org/10.1016/j.envpol.2016.11.005.

(C) 2022 by the authors. Submitted for possible open access publication under the terms and conditions of the Creative Commons Attribution (CC-BY-NC-ND) license (http://creativecommons.org/licenses/by/4.0/). 